\title{
Adverbi sisaldavate struktuuride tekstifunktsioonidest eesti ilukirjandus- ja õppijakeeles
}

\author{
PILLE ESLON \\ Tallinna Ülikool
}

Ülevaade. Artiklis kirjeldatakse eesti ilukirjanduskeele olulisemaid adverbi sisaldavaid trigramme. Need täidavad tekstifunktsioone (viiteseosed, modaalne hinnang, rõhutamine), mis aitavad tagada tekstide sidususe ja esituslaadi sujuvuse. Teisalt on adverbi sisaldavad struktuurid aluseks uute leksikaalsete üksuste moodustamisele, verbist vasakul peamiselt ühendverbidele (hästi välja tuleb, ootamatult peale sattuda, siit ära minna), harvem ka väljendverbidele (ikka puhtust pidanud, ka märki tabanud). Eesti õppijakeeles on adverbi sisaldavate struktuuride kasutamine nihestunud ja perifeerne nähtus - struktuur on sama, erineb leksikaalne ja morfosüntaktiline varieerumine ning osakaal valimis. Võrreldes emakeelekõnelejaga on õppijad eelistanud kasutada leksikaalgrammatilisi stereotüüpe (nt kus inimesed on, siis inimesed ei), sõnavara piiratud, trigrammi komponentide sõnajärg ja semantilised seosed tihti ebaharilikud või vigased, mis laieneb õppija emakeele mõjul. See on paratamatus, kuna meil puudub teadmine adverbi sisaldavate struktuuride kasutamise reeglite kohta tekstis.

Võtmesõnad: eesti ilukirjandus- ja õppijakeel; mitmesõnalised kooslused; adverbistruktuuride tekstifunktsioonid; klasteranalüüs; n-grammid 


\section{Sissejuhatus}

Empiirilise uurimistöö teoreetiline väärtus oleneb suuresti analüüsimeetodi(te) otstarbekusest. Nähtused, mis ühtede meetodite kasutamisel esile ei tule, võivad ilmneda ja saada seletuse teiste meetodite abil. Seda eriti korpusuuringutes, kus andmete mõtestamine võib viia uurija üllatavate avastuste, seaduspärasuste ja uute tähelepanekuteni, kuna korpusanalüüs on varasemast empiirikute ja ratsionalistide metodoloogilisest dihhotoomiast vaba. Aja jooksul on uurimisainese korpuslingvistilisest käsitlusest järk-järgult kujunenud uus metodoloogiline suund, mis vastandub eelmise põlvkonna teoreetilise mõttele. (Vt Meurers 2005; Anthony 2013)

Representatiivsetele tasakaalustatud korpustele tuginevad uurimused on olemuselt kasutuspõhised. Teooriate analüüs (vt Ibbotson 2013) ja konkreetne tekstikasutus annab ettekujutuse eri suundadest ja tegelikest võimalustest semantika-grammatika vahekorra seletamisel. Nii suulises kui ka kirjalikus tekstis on lekseemide, keelestruktuuride ja vormide kombineerimisel kindlad piirangud ning varieerumise piirid. Tehtud valikuid iseloomustavad ratsionaalsus, optimaalsus, regulaarsus, sagedus, osakaal valimis (vt nt Ellis 2006). Sagedus märgib tekstikasutuses sama, mida invariant grammatikas. Selles mõttes on kõige sagedamini esinenud keelekasutusmustrid invariantsed (vt Eslon 2014: 56). Tekstikasutuse seaduspärasused avalduvad keeleüksuste lineaarse kooskasutuse tingimustes, mida saab uurida erinevate tekstitöötlusprogrammide abil, nt MonoConc Pro, WordSmith Tools, KWIC, SketchEngine, Wmatrix, Xaira, k.a eesti keele tarkvaral põhinev Klastrileidja (Ots 2012), mis töötab andmekaeve põhimõttel (vt lähemalt Trainis \& Allkivi 2014: 283-285).

Võimalus analüüsida automaatselt eestikeelset tekstikasutust, tuua esile n-gramme ehk mitmesõnalisi lineaarseid kooslusi, reastada need regulaarsuse, olulisuse ja erinevate tekstiliste funktsioonide alusel - kõik see on avanud lingvistika jaoks põhimõtteliselt uue uurimistasandi, mis leidnud avarat rakendust inglise keele alusel. Eesti keele tekstikorpusi on seni kasutatud peamiselt andmeallikana, neist leitud näidete lingvistiline 
ja korpuslingvistiline analüüs on võimaldanud kirjeldada erinevaid grammatikanähtusi, diakroonilisi protsesse, luua kognitiivseid mudeleid jm. Klastrileidja programmi rakendamine tõstab fookusesse mitmesõnalised lineaarsed kooslused ehk sõnajadad, millele tekstiloomes toetutakse ning mis on erinevatele allkeeltele, keelekasutusvariantidele ja individuaalsele keelepruugile omased.

Mitmesõnalised kooslused (ingl multi-word co-occurrences) on ülemmõiste, hõlmab nii leksikaalselt ja süntaktiliselt vabu kui ka seotud ühendeid, mis võivad olla esile toodud kas lingvistiliselt või statistiliselt (vt Evert 2005: 15-20). Seotud ehk püsiühendite (multi-word expression) "all mõeldakse kahe või enama sõna(vormi) ühendit, mida mingi tähenduse väljendamiseks on tavaks koos kasutada" (Kaalep \& Muischnek 2009: 157); selle definitsiooni alla mahuvad nii idiomaatilised kui ka kollokatiivsed ühendid. Francesca Masini (2005: 145-146) väitel on püsiühenditel kahene staatus: ühelt poolt on tegu fraasistruktuuride ja teisalt leksikaalsete üksustega (tavaliselt võrdsustatud sõnaga). Seega kuuluvad püsiühendid süntaksi ja leksika piirimaile ning neil on tekstis topelt funktsioonid. Näitena vaatleb Masini itaalia keele fraasikonstruktsioone, mille funktsionaalne vaste on partikkelverbid.

Diskursuse uurijad on rakendanud vormeli mõistet (formulaic sequences), millele on antud üle viiekümne seletuse. Tegu on samasuguse ülemmõistega nagu mitmesõnalised kooslused. Vormelitena on vaadeldud sõnavormide järjendeid, kuhu paigutuvad nii erinevat liiki mitmesõnalised üksused (multi-word units), kollokatsioonid (collocations) ja idioomid (idioms) kui ka leksikaalsed kimbud (lexical bundles) ja fraasid (lexical phrases). Vormelid on konventsionaalsed terviküksused, mida sellistena tajutakse, jäetakse meelde, produtseeritakse ja kasutatakse. Nende kinnistumine tuleneb korduvast kommunikatiivsest vajadusest, nende kasutamine kiirendab suhtlust, suurendab teksti mahtu poole või veerandi võrra ning võimaldab teksti poole kiiremini lugeda ja sellest aru saada. Vormeleid esineb sagedamini suulises kõnes, kuid ka kirjalike tekstide produtseerimisel ja mõistmisel on neil oluline roll, osa neist kuulub registrimarkerite alla. (Vt Conklin \& Schmitt 2008: 73-76, 86) 
Struktuurianaloogia põhjal saab konventsionaalsete vormelite alusel moodustada uusi mittekonventsionaalseid järjendeid, millest võivad korduval kasutamisel kujuneda uued terviküksused, nt nagu produktiivse malli alusel moodustatud eesti keele liitpredikaadid (vt Muischnek \& Sahkai 2010: 296 jj), samuti ühend- ja väljendverbid (vt Eslon 2014: 67).

n-grammide leidmine tekstist ja nende järjestamine morfosüntaktilise struktuuri, selle leksikaalse, morfoloogilise ja süntaktilise varieerumise piiride, esinemissageduse ning osakaalu alusel toob välja tekstiloome jaoks olulised kinnistunud ja vabad mitmesõnalised kooslused. Neil on selged tekstilised funktsioonid, nende kaudu avanevad keele kui süsteemi ja leksika koosmõju võimalused.

Käesoleva artikli eesmärk on tutvustada uurimistulemusi, mis saadud eesti ilukirjandus- ja õppijakeele trigrammide võrdlemisel (vt Trainis \& Allkivi 2014; Eslon 2014). Nähtub, et eesti ilukirjanduskeele kasutusmustrite seas eristuvad adverbi sisaldavad keelestruktuurid ja sõnaliikidest adverb, samas kui eesti keele õppijad püüavad neid igati vältida. Kerkib küsimus, mille jaoks emakeelekõneleja nimetatud struktuure kasutab ning mis põhjustel õppija neid väldib.

\section{Adverbi sisaldavate struktuuride tekstifunktsioonidest}

Adverbi tekstifunktsioonide avamisel toetun ilukirjandus- ja õppijakeele võrdleva analüüsi tulemustele, aluseks lauses verbist vasakule jääv kontekst (vt Eslon 2014). Toon paralleele ilukirjanduskeele mustritest, mille otsingut ei piiratud (vt Trainis \& Allkivi 2014). Nimetatud uurimuste tarbeks on Klastrileidja abil leitud trigrammid, sest lekseemi kasutuskonteksti tavapäraseks pikkuseks kirjalikus tekstis on \pm 2 sõna. Sellest on lähtunud ka Martin Chodorow ja Claudia Leacock (2000) statistilise süsteemi ALEK (Assessing Lexical Knowledge) loomisel, mis tuvastab standardkeele alusel inglise keele sõnakasutuse tüüpilised kontekstid, võrdleb neid õppija keelekasutusega ja leiab automaatselt vead. Kathy Conklin ja Norbert Schmitt (2008: 74-75) viitavad Longmani suulise ja kirjaliku inglise keele grammatikale, milles tuginetakse kolmest-neljast 
üksusest koosnevatele leksikaalsetele kimpudele, mis katavad 28\% suulisest kõnest ja 20\% akadeemilisest tekstist (teistel andmetel kuni 40\%) ning on olemas kõikides keeltes.

Eesti ilukirjanduskeele klasteranalüüs tugineb samuti trigrammidele. Jekaterina Trainise ja Kais Allkivi (2014: 286 jj) järgi on selles kõige suurem osakaal adverbialgulistel morfoloogilistel mustritel (24,9\%), mis jagunevad põhiliselt kolme alamklassi vahel: adverb-substantiiv ehk D-S (29,4\%), adverb-verb ehk D-V (25,4\%) ja adverb-adverb ehk D-D (19,1\%). Alamklass D-V iseloomustab verbist vasakule jäävat konteksti, selle sagedamad klastrid on Trainise ja Allkivi (2014) ning Esloni (2013) järgi samad: adverb-adverb-verb ehk DDV (39,8\%), adverb-verbverb ehk DVV (24,8\%), adverb-konjunktsioon-verb ehk DJV (12,6\%), adverb-substantiiv-verb ehk DSV (11,2\%) jm. Nt DDV - nü̈̈d küll ei; DVV - veel ei liikunud, muidugi ei olnud; DJV - <tõstis> üles ja küsis, $<$ panen> kinni ja jätan, <andis> tagasi ja läks; DSV - ikka puhtust pidanud, ka märki tabanud. Trainise ja Allkivi (2014) ning Esloni (2013) uurimustes on vahe klastrite osakaalus suhteline ning tuleneb sellest, et Trainis ja Allkivi võtsid aluseks kaks ning enam korda, Eslon viis ning enam korda kasutatud trigrammid. Samas pole see kuidagi mõjutanud klastrite olulisusjärjestust: mõlemal juhul on see DDV - DVV - DJV DSV (vt joonis 1).

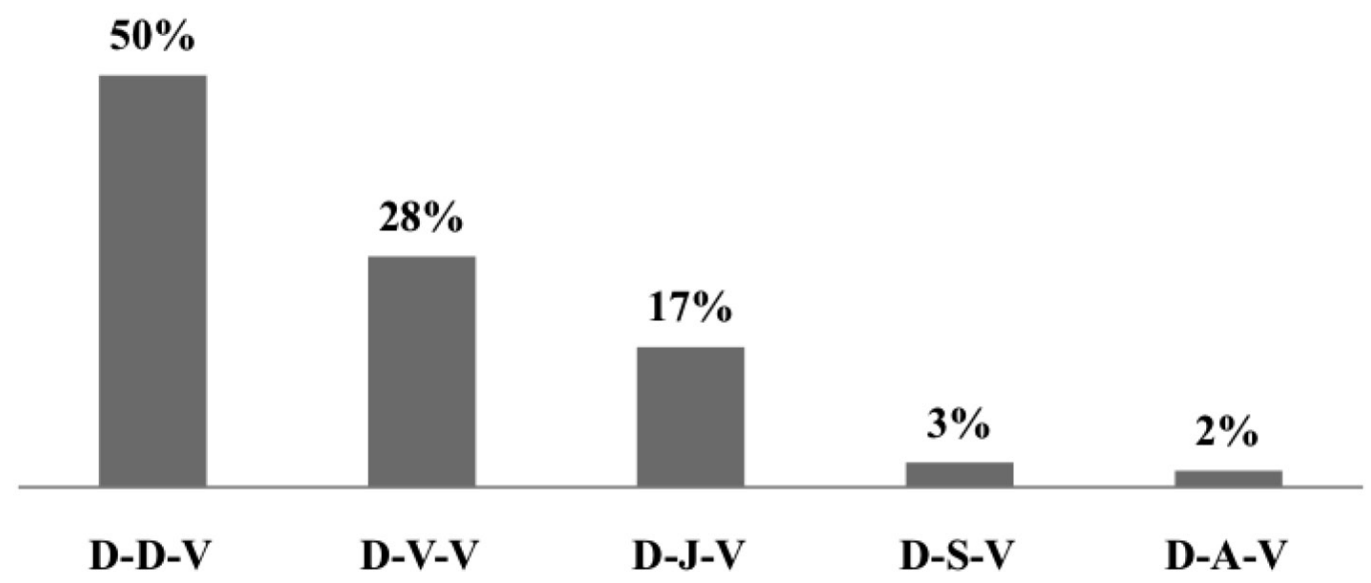

Joonis 1. Klass D-V: ilukirjanduskeele adverbialgulised klastrid Eslon 2013 järgi 
Analüüs näitab, et adverbi sisaldavad struktuurid täidavad üldjuhul kahesuguseid tekstifunktsioone: 1) neid kasutatakse viiteseose vahendina - adverb võib olla määruseks, omada modaalpartikli ja rõhusõna funktsioone; tegu on adverbi funktsionaalse potentsiaali avardumisega (adverbi grammatiseerumise kohta eesti keeles vt Küngas 2014; Valdmets \& Habicht 2013; Valdmets 2010; Veismann 2009); 2) adverbi sisaldavate struktuuride alusel tekivad uued vabad ning seotud ühendid - leksikaalsed üksused; tegu on kinnistunud adverbiliste struktuuridega, mille põhjal saab moodustada praktiliselt piiramatul hulgal mitmesõnalisi kooslusi, millest aja möödudes võivad kujuneda idiomaatilised üksused, k.a ühendverbid. Seetõttu võib verbist vasakul paiknevaid adverbilisi struktuure pidada ühendverbe genereerivateks struktuurideks, eelkõige järjendit adverb-adverb-verb, mille kõigist kasutusnäidetest moodustavad valdava osa ühendverbid: kuskile ära sõitnud, veel ümber riietunud, isegi mööda käinud, alati ette teatanud, juba ära sulanud; uuesti üle kuulatud, thedasti täis kirjutatud, õigeaegselt maha võetud jne. Klastrileidjat kasutamata olen varem teiste meetoditega analüüsinud lekseemidest tegema, andma, saama, võtma paremale jäävaid mitmesõnalisi kooslusi eesti õppijakeeles. Töö käigus sattusin analoogsele seaduspärasusele elutut partitiivset objekti sisaldavas verbi-substantiivi struktuuris, mille leksikaalne varieerumine võib samuti olla põhimõtteliselt piiramatu (v.a piirangud semantilistes seostes) ning vabadest ühenditest võivad aja jooksul samuti kujuneda idiomaatilised üksused, k.a väljendverbid (nt vabad ühendid leiba tegema, eratunde andma ja väljendverbid nalja tegema ja nõu andma). Trainis \& Allkivi (2014: 290 jj) on välja toonud, et eesti ilukirjanduskeeles on adverbi sisaldavate trigrammide osakaal suur mitte ainult verbist vasakul, vaid ka paremal. Nii hõlmab verbiga algav morfoloogiline klass 17\% valimi mahust, sisaldab kaheksat alamklassi, millest olulisim on adverbilõpuline V-D (41,7\%, nt mõtleb Leopold nukralt), mis omakorda jaguneb viie klastri vahel: VDD (36,6\%, nt oli üsna kõrgelt, olin juba päris, on ju lõpuks, oleks nagu veel), VSD (22,0\%, nt pööras pilgu ära, võttis buketi vastu, pani noa kõrvale), VPD (21,1\%, nt oli ta salaja, oli ta siinkandis, oli ta vahepeal), VVD (17,9\%, nt ei kao kuhugi, ei 
suuda kauem, ei lähe sinna, ei ole võlgu, ei ole ainult), VJD (2,4\%). Selles loetelus on ühendverbide kasutus seotud klastriga VSD, kus substantiiv asub verbivormi ja verbipartikli vahel, nt pani noa kõrvale. Kuigi ühendverbe genereerivad struktuurid paiknevad valdavalt verbist vasakul, on vähemalt üks nendest (VSD) kasutusel ka verbist paremal. Edaspidi on kavas saada täielik ülevaade ka nendest objektikäändelist substantiivi sisaldavatest struktuuridest õppija ja emakeelekõneleja tekstikasutuses, ent juba praegu saan väita, et lause predikatiivsest keskmest (verbist) vasakule ja paremale jäävas kontekstis kasutatakse korduvalt kindlat liiki morfosüntaktilisi struktuure, millel piiratud morfoloogiline ja põhimõtteliselt piiramatu leksikaalne varieerumine. See omadus tagab struktuuride valmisoleku genereerida pidevalt uusi keeleüksusi ja realiseerida niimoodi keele kui süsteemi funktsionaalset potentsiaali. Seda võimalust ei kasutata kunagi täiel määral, sest korduvad kommunikatiivsed vajadused toetavad konventsionaalsete mustrite kujunemist, millele inimesed tekstist arusaamisel või tekstiloomes tavaliselt toetuvad. Küsimus seisneb selles, kui oskuslikult ja loovalt suudab emakeelekõneleja keelevaramu võimalusi kasutada ning kui ratsionaalselt ta seda teeb. Siin on emakeelekõneleja ja õppija probleemid erinevad, kuid psühholingvistiline ja sotsiofunktsionaalne alus terviküksuste kasutamiseks suhtluses on universaalne.

Järgnevalt kirjeldan verbist vasakul paiknevate adverbi sisaldavate struktuuride funktsioone emakeelses tekstiloomes, võrdlen seda õppija tekstiloomega, toon esile erinevused ja seletan nende põhjusi. Ühelt poolt on tegu adverbi funktsioonide avardumise ning teisalt adverbi sisaldavate struktuuride olulisusega teksti produtseerimisel.

\subsection{Adverbi funktsioonide avardumine}

Grammatikate järgi on adverbi põhifunktsioon eri liiki määrused. Samas näitab adverbistruktuuride eelistamine substantiivi, verbi või adjektiivi sisaldavatele struktuuridele verbist vasakul paiknevas kontekstis, et adverbistruktuure läheb enamasti vaja viiteseoste loomiseks või 
muudel kommunikatiivsetel eesmärkidel nagu kõnesoleva fookusesse tõstmine, sellele subjektiivse hinnangu andmine, sh modaalne, ratsionaalne ja emotsionaalne hinnang. Üheski loetletud funktsioonis ei esine adverb iseseisvana, vaid trigrammi struktuuri lahutamatu komponendina. Kuigi trigrammides pole eristatud adverbe ja proadverbe, võib mõningatel juhtudel märgata adverbide või proadverbide eelistamist. Olen sellele analüüsis osutanud (nt seos trigrammi struktuuri ja adverbi paiknemisega selles), kuid järjekindel adverbi-proadverbi kasutuserinevuste kirjeldus pole siinse uurimuse eesmärk.

\subsubsection{Adverbi sisaldavate struktuuride kasutamine määrusena}

- Eitava kõne järjendis adverb-adverb-verb (DDV) on esimene komponent pigem määruslikus ja teine pigem rõhu- või modaalsõna funktsioonis, nt nagu ajamäärused nüüd, praegu, siiani, edaspidi, põhjus-tagajärg seost väljendav proadverb siis, kohamääruslik proadverb seal koos rõhusõnadega küll, enam, rohkem, ka ning modaalsõnad vist, tõesti, nt nü̈̈d küll ei, nü̈̈d enam ei, nü̈̈d sisse ei, praegu rohkem ei, siiani vaja ei, edaspidi enam ei, siis $k a$ ei, siis vist ei, siis tõesti ei, seal ees ei.

- Jaatava kõne järjendis adverb-adverb-verb (DDV), kus tavaliselt on kasutatud olema-verbi indikatiivi preesensi 3. pöörde vormis, võivad mõlemad adverbid või adverbi-proadverbi kombinatsioon olla määruse funktsioonis või üks määruse ja teine rõhusõnana. Regulaarsust erinevate funktsioonide ja adverbilise komponendi paiknemise vahel trigrammis on raske leida, nt seal, all (koht), üksi (hulk), nü̈̈d, vahetevahel (aeg): seal all on, päris üksi on, nü̈̈d juba on, veel vahetevahel esineb.

- $\quad$ Eitava ja jaatava kõne järjendis sidesõna-adverb-verb (JDV) on (pro) adverbil enamasti aja- (kuid nüüd ei, ent tookord ei, ja seekord ei; aga nüüd sündis, aga siis oli, kuid siis tõmbus, ning millal tuleb, ja nüüd on), koha- (aga kaugemale ei, ja kuhu ei, kuid siin ei; ja sealtkaudu tuli, ja kaugel vastas, ja sealt hakkab) ja viisimääruse (ja hooletult 
teatas, kuid järsku tuletas, aga korraga sai) funktsioon; kasutatud on rinnastavat seost, verb on enamasti imperfekti, harvem preesensi ainsuse 3. pöördes.

- Jaatava ja eitava kõne järjendis substantiiv-adverb-verb (SDV) on adverb viisimäärus (põlv ebameeldivalt tuikas, padigi justkui torises, sisemus isemoodi sügelema, asja korralikult teha; ema kergelt ei), harva tähistab tegevuse määra (süda natuke kripeldas); verbi on kasutatud imperfekti ainsuse 3. pöördes või predikatiivse ma- ja $d a$-infinitiivi vormis.

- Järjendis verb-adverb-verb (VDV) on adverb viisi- (oli järsult keeldunud, oli rõõmsalt noogutanud, oli ootamatult avanenud) ja ajamäärus (oli äsja abiellunud, oli seni olnud, oli algul ehmunud, oli kohe surnud); verbi on kasutatud pluskvamperfektis.

Niisiis on määruslike funktsioonide esinemine morfosüntaktiliselt piiratud, sõltub trigrammi morfoloogilisest struktuurist (DDV, JDV, SDV, VDV) ja kõneliigist, on seotud piirangutega verbi grammatilise vormi (preesens, imperfekt, pluskvamperfekt) ja lekseemide valikul (sagedam on nt nü̈̈d ajamäärusena). Jälgitav on seos struktuuride SDV ja VDV, verbi imperfekti ja pluskvamperfekti ning viisimääruse eelistamise vahel; struktuuris DDV on esimese komponendina eelistatud proadverbe (nt siis, siin, seal, seekord, tookord).

\subsubsection{Adverbi sisaldavate struktuuride kasutamine viiteseose vormistamiseks}

Nii (osa)lausete kui ka suuremate tekstilõikude terviklikkuse ja esituslaadi sujuvuse eesmärgil on kasutatud kolme lausealgulist adverbi sisaldavat struktuuri: sidesõna-adverb-verb (JDV), adverb-adverb-verb (DDV) ja adverb-verb-verb (DVV).

- JDV lause alguses jaatavas kõnes: Aga ikkagi oli, Ja ometi oli, Ja siis oli, Kuid seejärel oli; Ning sealgi olid, Ja siis olid, Ent ometi tundusid, Aga võib-olla hukkusid; Kuid kahtlemata oli, Aga ilmselt jäi, Ja nõnda tuli, Ja korraga meenus, Ent samas oli, Aga juba oli. Lausealgulisele 
struktuurile JDV on iseloomulik morfoloogia- ja leksikavahendite piiratus: rinnastavad sidesõnad (tavaliselt ja, ent, aga) partikli funktsioonis, adverb rõhu- (ikkagi, ometi, juba) ja modaalse hinnangusõnana (võib-olla, kahtlemata, ilmselt) või proadverb määrusena (siis, seejärel, sealgi, nõnda, samas), verb indikatiivi imperfektis ainsuse 3. pöördes (eelistatakse olema-verbi). Nimetatud morfosüntaktilised ja leksikaalsed kooslused moodustavad tekstilise terviküksuse, mis seob eelneva informatsiooni järgnevaga (Ta elas tagasihoidlikult, üritades olla rahul ja leplik oma kasina eluviisi ja väheste nõudmistega. Aga ikka oli süda raske ja midagi nagu puudu), väljendades järgneva tõeväärsust (Nüüd tunnevad nad omal nahal, et asjad on halvasti. Aga võib-olla oleks viimane aeg midagi ette võtta), edastades sündmuste loogikat, kõrvutades olukordi, sündmusi, isikuid, täpsustades järgneva lausega eelnevas saadud teavet jm (Kommentaariks võib lisada, et udmurtidel oli tõesti komme ohvrihiies küünlaid põletada. Ent samas loeti ohvrihiies nagu palvekojaski kõige pühamaks paigaks tuleaset).

- JDV osalause alguses nii jaatavas kui eitavas kõnes. Jaatava kõne struktuur sisaldab a) olema-verbi indikatiivi imperfekti ainsuse 3. pöördes: ja kindlasti oli, ning siis kadus, kuid äkki tuli, ja juba algaski, aga võib-olla oli, aga nüüd sündis, ja korraga meenus, kuid siis tõmbus, aga nii tundus, ja sealtkaudu tuli, kuid ometi oli; b) verbe indikatiivi imperfekti ainsuse 3. pöördes: ja hooletult teatas, kuid järsku tuletas, ja kaugel vastas, ja siis toimetas, ja vahel pistis, aga korraga sai; c) verbe indikatiivi preesensi ainsuse 3. pöördes: ning millal tuleb, ja sealt hakkab, ja siis on, vaid hoopis ronib, ja ikka lipsab, aga hiljem rahuneb, ja nüüd on, aga ometi on. Eitava kõne näiteid on vähem: ning seepärast ei, ja nii ei, kuid nüüd ei, aga kaugemale ei, ent tookord ei, või koguni ei, ja seekord ei, kuid siin ei, ja muidugi ei. Rinnastavale sidesõnale (ja, ning, aga, kuid) järgneb adverb, mida on kasutatud eelneva informatsiooni tõeväärsuse hindamiseks (kindlasti, võib-olla, muidugi), esiletõstmiseks (ometi, koguni) ning tegevuse iseloomustamiseks korduva (ikka) 
või ootamatuna (äkki, korraga, järsku). Adverbidega edastatakse ka määruslikke tähendusi (hiljem - aeg, kaugel - koht jm). Proadverbe (siis, sealt, tookord, seekord) on kasutatud tagasiviite vahendina.

Niisiis on struktuuri JDV vaja teksti- ja lausesiseste viite- ning hinnanguseosteks, lause tasandil ka tegevuse aktsionaalsete tähendusvarjundite edastamiseks. Helle Metslang, Karl Pajusalu ja Külli Habicht (2014: 141) on rinnastavate sidesõnade $v \tilde{o} i$, ja ning aga kasutamise kohta lause vasakus perifeerias partikli funktsioonis esile toonud nende olulisuse teksti organiseerimisel: seostamine eelneva kontekstiga, selle jätk, vastandus ja tagasihaare, samuti subjektiivseid tähendusi edastavad elemendid.

- DDV lause alguses jaatavas ja eitavas kõnes: Umbes nii oli, Alles hiljem selgus, Liiga hilja oli; Kas tõesti oli, Kui palju oli, Kust küll pärines; Mitte iialgi ei, Mitte kunagi ei, Seal täna ei, Nii ruttu ei. Eraldi vaadelduna on DDV-struktuuri adverbidel erinevad funktsioonid ning raske on leida selles seaduspära või kombineerimise printsiipi, nt rõhusõna (liiga) + määruslik laiend (hilja); küsisõna (kas) + subjektiivmodaalne hinnangusõna (tõesti); proadverb (seal) + määruslik laiend (täna). Ent tekstilise terviküksusena võtab lausealguline DDV-struktuur kokku kõnealuse informatsiooni, luues silla jätkamaks uue teemaga: Carlitos ei keeldunud mängimast, kuid keeldus soojendama minema, sest oli juba soojendusest tulnud ja valmis mängu minema. <...> Umbes nii oli selle jama algus (kokkuvõtlik subjektiivmodaalne hinnang eespool kirjeldatule). Küsisõna või kas-partikliga algavat DDV-struktuuri kasutatakse mitmeti: nii teksti pealkirjana kui ka teksti alguses, kus autor püstitab küsimuse, mille üle tasub arutleda või millele oleks vaja leida vastus, nt Kust küll pärinevad ettekujutused, et meie tüdrukud peavad saama roosad tekid ja poisid sinised, et ühed on tehtud suhkrust ja jahust ja maasikavahust, teised aga tiigrist ja konnast ja kutsikahännast? Sama lausealguline struktuur võib olla ka (mikro)teema käsitluse lõpus retoorilise või üldise kas-küsimusena, millele tekst otsest vastust ei anna, ent mõlemal juhul on see üks vahendeid autori hinnangu edastamiseks või vihjamisi ütlemiseks, nt Kõik ettepanekud 
olid head. Kas tõesti olid? (loe: kas ikka olid, st 'ei olnud'; 'pole tõeväärne'; võimalik ka teema jätkamiseks mõeldud üldküsimusena).

- DVV lause alguses eitavas kõnes: Võib-olla ei olnudki, Sealpool ei olnud, Ka ei paistnud, Tegelikult ei olnud, Ilmselt ei tulnud, Teiseks ei mahtunud, Nüüd ei tulnud. Selles struktuuris on adverbe kasutatud subjektiivmodaalse hinnangusõnana (võib-olla, tegelikult, ilmselt - sündmuse tõeväärsus), (pro)adverbe määrusliku laiendina (sealpool - kohamäärus, nü̈̈d - ajamäärus), rõhusõnana $(k a)$, loogilise järjestuse väljendamiseks (teiseks). Verb seisab eitava kõne perfekti vormis: Juba 1992. aastal jäi asi seisma. Võib-olla ei olnudki (eelnevate sündmuste tõeväärsuse subjektiivmodaalne hinnang) ühiskondlikke jõude, et rahvuslikud ringkonnad oleksid suutnud eetikarevolutsiooni lópuni viia.

Vaadeldud lause- ja osalausealgulistes adverbi sisaldavates struktuurides, mida kasutatakse tagasi- ning edasiviite vahendina, võib sõnajärg ja leksika varieeruda, ent domineerivad järjendid on siiski JDV, DDV ja DVV. Need grammatilised struktuurid konventsionaliseeruvad kindlates tekstilistes funktsioonides, tagades teksti terviklikkuse ning esituslaadi sujuvuse.

\subsubsection{Adverbi sisaldavate struktuuride kasutamine modaalse ja ratsionaalse hinnangu eesmärgil; kõnesoleva fookusesse tõstmine, sidumine eelneva või järgneva informatsiooniga}

Sel otstarbel on kasutatud nii eespool kirjeldatud adverbi sisaldavaid lause- ja osalausealgulisi struktuure kui ka osalause sees verbist vasakul paiknevaid trigramme. Klastrileidja tõi esile hulga osalausesisese DDVstruktuuri jaatava ja eitava kõne näiteid, millega iseloomustatakse tegevust, potentsiaalselt ka tegijat, kogejat või omajat.

- Eitav kõne: enam sugugi ei, just siin ei, liiga palju ei, üldsegi mitte ei, kunagi enam ei, nii eredalt ei, küll kaasas ei <kanna>, enam siiakanti ei <sattu>, päris lahti ei $<\mathrm{saa}>$, ju kaasa ei $<$ tule>, targu muidugi ei $<$ talita $>$, enam kaugemale ei <läinud $>$, eriti enam ei. Nende 
trigrammide tekstikasutuses võib sõnajärg varieeruda: kui enam sugugi ei taha nendega rääkida kui sugugi enam ei taha nendega rääkida kui ei taha nendega enam sugugi rääkida kui nendega sugugi ei taha enam rääkida kui nendega sugugi enam rääkida ei taha, mis võimaldab fookusesse tõsta erinevat informatsiooni, kuid levinum on siiski järjend DDV: Vihmavarju ma küll kaasas ei kanna. Emakeelekõneleja tajub sõnajärje muutustest tulenevaid tähendusnüansse isegi siis, kui tegu pole kuigi loomuliku sõnajärjega, kuid raskusi tekib eesti keele õppijal. Seetõttu on oluline õppida kasutama levinud sõnajärjemalle.

- Jaatav kõne: väga tublisti kosunud, sinna juhuslikult tulnud, üsna jämedalt väljendunud, seal varemgi olnud, juba ammu juhtunud, õieti kunagi olnud, ikka veel lakanud, peaaegu juba hakanud, küll päriselt kadunud, ju põhjalikult analü̈̈sinud, juba niivõrd harjunud, nii südamlikult kutsunud, kõige rohkem passinud. Jaatava kõne DDVstruktuuri on kasutatud analoogselt eitava kõnega, kus (pro)adverb on enamasti määrus, harvem modaal- või rõhusõna. Varieerub verbi grammatiline vorm ja funktsioon. Tavaliselt on verb mineviku liitaja vormis personaalis, impersonaali kasutus on erand. Verbivormi varieerumine piirdub predikatiivse $m a$-infinitiivi, indikatiivi imperfekti ja preesensi ainsuse 3. pöörde ning objektina või liitpredikaadi koosseisus kasutatud da-infinitiiviga: a) ma-infinitiiv - sinna siiski minema, veel täna minema, nüüd tõenäoliselt minema, sinna kohe minema, ju ka helistama, ühtepuhku siin käima, lausa naeruväärselt võbisema, siis omakorda kalduma; b) indikatiivi imperfekti ainsuse 3. pöörde vorm - ammu juba puudus, alles nü̈̈d hakkas, kas üldse oli, kõige valusamini lõi, päris kenasti lõikas, vähemalt väliselt andis; c) indikatiivi preesensi ainsuse 3. pöörde vorm (kasutatud enamasti olema-verbi) - seal all on, just nii ongi, päris üksi on, ainult siis on, siis õieti on, nüüd juba on, siis üldse on, nii kangesti meeldib, üha enam kaugeneb; d) da-infinitiiv objekti funktsioonis - nii sügavalt kummardada, ka korraga likvideerida, praegu sinna minna, just niipalju kosuda, enam kusagilt leida, kunagi täpselt öelda; e) da-infinitiiv 
liitpredikaadi koosseisus - kuigi põhjalikult uurida, ka sinna viia, siin ikka öelda, siis üldse rabelda, enam kaua kesta, veidike üksinda olla, nii palju suitsetada.

Kõik DDV-struktuuri lausesisesed kasutused on seotud ühelt poolt kindlat liiki kontekstiga, nt liitpredikaati kuuluv ma-infinitiiv on koos modaal- või faasiverbi finiitvormiga (<peab, hakkab> sinna siiski minema), da-infinitiivi sisaldava trigrammi kahele adverbilisele komponendile eelneb kontekstis modaalverb või hinnangusõna - seda konteksti kasutatakse võimatuse ja keelu väljendamiseks (<ei saanud> kuigi põhjalikult uurida, <ei tohi, pole kasulik> nii palju suitsetada). Teisalt on DDV-struktuuris näha verbi grammatilise vormi varieerumist (Samas alles nü̈̈d hakkab/hakkas mulle see asi kohale jõudma ja iga päev mõtlen vähemalt viis korda, miks pakuti mulle kohta, mida varasemalt on ...). Varieeruda võib ka lause sõnajärg, nt Samas hakkab/hakkas mulle alles nü̈̈d kohale jõudma, miks ... Samas hakkab/hakkas kohale jõudma alles nü̈̈d, miks ..., kuid kasutusmustrina tuleb esile siiski järjend DDV. Kirjeldatudd nähtused vajavad üksikasjalikumat uurimist seoses adverbide ja proadverbide eristamisega.

\subsection{Adverbi sisaldavate struktuuride potentsiaal ühendverbide genereerimisel}

Enamuse (osa)lause sees paiknevate adverbi sisaldavate trigrammide alusel moodustatakse ühendverbe, vähesel määral tuli ilukirjanduskeele valimis esile ka väljendverbe. Eesti keele ühendverbe genereeriv struktuur on DDV, harva esineb samas funktsioonis ka SDV, mõningaid näiteid leidus VDV- ja PDV-struktuuride hulgas. Väljendverbe genereeriv struktuur verbist vasakule jäävas kontekstis on DSV (<on, oli> ikka puhtust pidanud, <on, oli > ka märki tabanud, <polnud > veel aru saanud, <ei ole> üldse aru saanud, kuidagi sotti ei <saanud>, siis aru ei $<$ saanud $>$ ), kuid selle osakaal verbist vasakul paiknevas kontekstis on ebaoluline (vaid 3\%). Seega sisaldab verbist vasakul paiknev kontekst adverbistruktuure, millel potentsiaal genereerida ühendverbe. 
- DDV-struktuuri kasutatakse enamasti jaatavas kõnes, esimene komponent on määruse funktsioonis, järgneb grammatiseerunud verbipartikkel, kolmas on piiratud vormikasutusega verb: a) mineviku liitaja personaali ja impersonaali vormid - veel üle läinud, isegi ära käinud; uuesti üle kuulatud, paksult kinni mähitud; b) verbi finiitvorm indikatiivi imperfekti ja preesensi ainsuse 3. pöördes - lõpuks välja ilmus, jälle ette tuli; ükskord vahele jääb, hästi välja tuleb; c) predikatiivne ma-infinitiiv - natuke tagasi minema, kiiremini edasi tormama; d) da-infinitiiv liitpredikaadi koosseisus - ootamatult peale sattuda, hädavaevalt läbi pugeda, tarvis ära lópetada või objekti funktsioonis - siit ära minna, kuhugi ära sõita, muidugi maha jääda). DDV-struktuuri trigrammide hulgas on üsna sage esikomponendi grammatiseerumine, kus adverbi on kasutatud a) rõhusõna funktsioonis - isegi, veel(gi), küll, ka, üldse, enam (isegi ära käinud, veelgi järele hõiganud, küll üles kaisutada), b) modaalse hinnangusõnana, mis tähistab tõesuse määra - muidugi ja lõpuks (muidugi maha jääda), c) loogilise järestuse tähistamiseks - lõpuks maha jättis ja ükskord 'lõpuks' vahele jääb. Esikomponendina on kasutatud ka eituspartiklit mitte (mitte sisse minna, mitte maha vaadata), modaalpartikleid tõesti ja lihtsalt (tõesti tagasi võtta, lihtsalt ümber kirjutada) ning modaalsete abisõnade klassi üle läinud adverbilist päritolu lekseeme tarvis ja vaja (tarvis ära lópetada, vaja järele kuulata).

- Teine ühendverbe genereeriv struktuur on SDV, kus keskmine komponent on verbipartikkel alla, peale, lahti, ära vm. Substantiivi kasutatakse enamasti genitiivse totaalobjekti (nime alla kirjutanud, tahte peale suruda, ukse lahti teha) või käändelise kaasnevusmäärusena (vestlusega kaasa läinud, ajurabandusega kokku kukkunud, kiiruga alla jooksnud), harvem subjektina (tervis tagasi tuli, tööjärg edasi liikus, vari ära lõppes). Ühendverb on enamasti mineviku liitaja koosseisus, kasutatud indikatiivi imperfekti ainsuse 3. pöördes, harvem da-infinitiivi vormis objektina.

- Järjendis VDV on ühendverb pluskvamperfekti vormis (oli kinni toppinud, oli lahti ununenud, oli kokku tulnud, oli sisse jäänud) ja 
pronoomeniga algavas järjendis PDV da-infinitiivi või imperfekti ainsuse 3. pöörde vormis (midagi ette võtta, midagi välja pressida; ta tagasi tuli, ta ilma jäi). Indefiniitse pronoomeni midagi ja 3. isiku lühivormi ta kordumine koos verbipartiklite ning samalaadsete verbivormidega (vastavalt predikatiivne $d a$-infinitiiv ja imperfekt) võimaldab nende kooskasutuse alusel genereerida uusi ühendverbe.

Niisiis on eespool kirjeldatud adverbi sisaldavatel järjenditel, eriti DDVstruktuuril omadus genereerida verbist vasakul paiknevas kontekstis ühendverbe. Analüüsitud morfosüntaktiliste struktuuride sees saab suhteliselt vabalt varieerida leksikat (SDV - nime alla kirjutanud > maja üle värvinud > raamatu maha kandnud > inimesi välja ajanud), muuta sõnajärge (Osa lapsi on oma töödele nime alla kirjutanud > oma töödele on osa lapsi nime alla kirjutanud > töödele on osa lapsi alla kirjutanud oma nime), samas kui verbi, substantiivi ja pronoomeni grammatiliste vormide kasutamine on piiratud (IME avaldusele söandas oma nime alla kirjutada vaid neli inimest > IME avaldusele kirjutas oma nime alla vaid neli inimest > Vaid neli inimest on oma nime IME avaldusele alla kirjutanud). Nende grammatiliste kitsendustega struktuuride põhjal saab genereerida uusi leksikaalseid üksusi. See on veelkordne näide keelekasutuse olemusest, mida eri keelte uurijad alates John Sinclairist (1991) ja lõpetades Arvo Krikmanniga (2004) on korduvalt väljendanud: keelestruktuurides domineerib pigem idiomaatilisuse kui avatud valiku printsiip.

\section{Miks väldib õppija adverbi sisaldavaid struktuure?}

\subsection{Adverbi sisaldavate struktuuride kasutuseelistused ilukirjandus- ja õppijakeeles}

Kui võrrelda adverbi sisaldavate keelestruktuuride osakaalu ilukirjandustekstides ja eesti õppijakeele valimis verbist vasakul paikneva konteksti põhjal, siis on ilmne, et õppija väldib nii adverbi kui ka adverbi sisaldavaid morfosüntaktilisi kooslusi (vt Eslon 2014: 58 jj; vrd jooniseid 
1 ja 2) - järelikult ka tekstilisi funktsioone, mida need struktuurid täidavad. Ennekõike tuleb see esile adverbialgulises klassis D-V, kus samadel klastritel on ilukirjandus- ja õppijakeeles erinev osakaal.

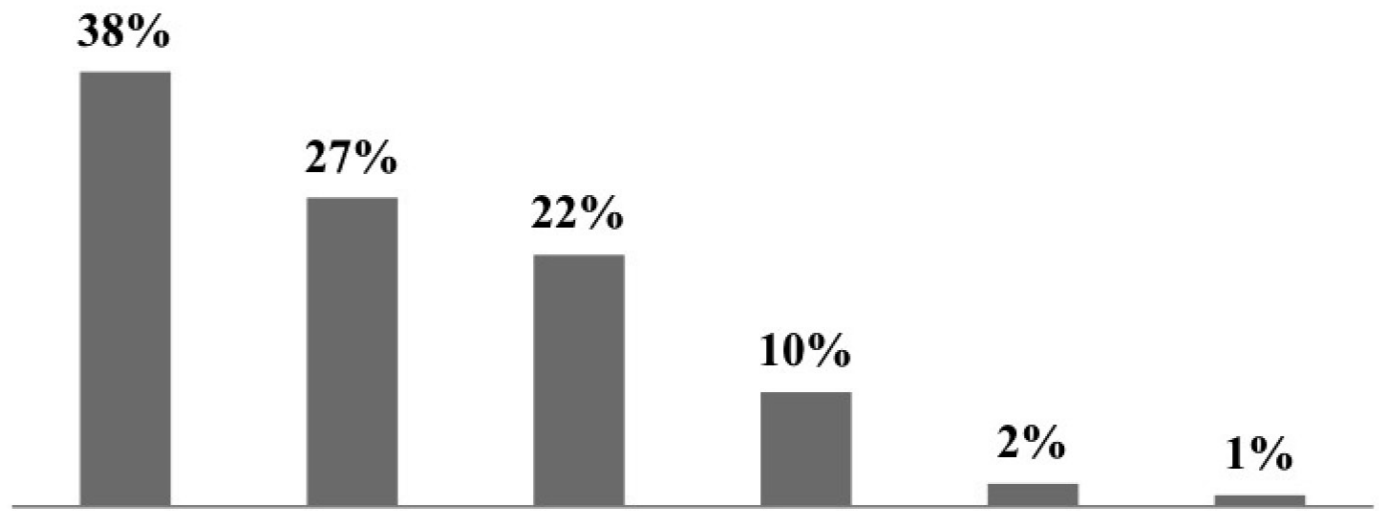
D-V-V
D-P-V
D-D-V
D-S-V
D-J-V
D-A-V

Joonis 2. Klass D-V: óppijakeele adverbialgulised klastrid Eslon 2013 järgi

Klassis D-V eelistatakse ilukirjanduskeeles kolme klastrit: DDV - osakaal 50\%, DVV 28\% ja DJV 17\%, nendega võrreldes on klastrid DSV 3\% ja DAV 2\% väheolulised (vt joonis 1). Õppijakeele klastrivarieerumine on avaram ja osakaal erinev: DVV 38\%, DPV 27\%, DDV 22\%, DSV $10 \%$, DJV 2\%, DAV 1\% (vt joonis 2).

Õppija eelistab eitava kõne struktuuri adverb-verbi eituspartikkel-verb (üldse ei sobi, enam ei jõua), emakeelekõneleja ühendverbe genereerivat järjendit DDV (kuskile ära sõitnud, veel ümber riietunud).

Õppija teine valik on adverb-pronoomen-verb (mõnikord see oli, praegu ma tahaksin, siis ma saan, veel mul on), ilukirjanduskeeles eitava kõne struktuur adverb-verbi eituspartikkel-verb (veel ei liikunud, muidugi ei olnud) ning järjend adverb-pronoomen-verb (DPV) pole seal üldse esile tulnud. Trainise ja Allkivi (2014: 301) andmetel ei kuulu DPV-sõnajärg (praegu ma tahaksin) emakeelekõneleja kasutuseelistuste hulka - klasteranalüüsi abil leiti vaid 30 trigrammi. Kuigi V2-sõnajärjega DVP-struktuuri näiteid (praegu tahaksin ma) esines ilukirjandusekeele valimis kolm korda sagedamini (kokku 102 trigrammi) kui DPV-struktuuri, on ka see emakeelses tekstikasutuses väheoluline. 
Kolmas õppijakeele struktuur on adverb-adverb-verbi eituspartik-

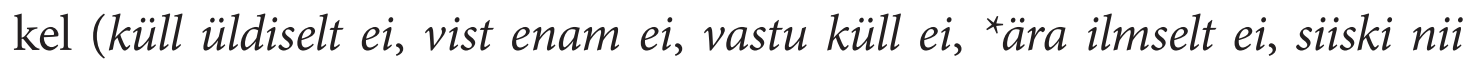
juhtub, ka väga meeldib), emakeelekõnelejal adverb-konjunktsioon-verb (<andis> tagasi ja läks). Õppijakeeles esines konjunktsiooni sisaldavaid trigramme väga vähe (hästi ja ei, enne ning toimub, hästi ja võib). Erineb ka adverbi funktsioon: ilukirjanduskeeles on see verbipartikkel, õppijakeeles hinnangu või orientatsioonisõna.

Struktuurid adverb-substantiiv-verb (õppijakeeles palju inimesi ei, täna ehitus on, siis elu läheb ja ilukirjanduskeeles ikka puhtust pidanud, ka märki tabanud) ning adverb-adjektiiv-verb (vastavalt kõige tähtsam on, väga hea on ja kuivõrd kena on, kui nõrk on, nii tuim on) olid mõlemas keelekasutusvariandis väheolulised.

Disproportsioon adverbialgulise klassi oluliste klastrite vahel näitab, et õppija alakasutab struktuure DDV ja DJV, ülekasutab DVV ja DSV, õppijakeele spetsiifiline nähtus on DPV-struktuur, mis ilukirjanduskeeles pole esile tulnud. Emakeeles olulised järjendid DDV 50\%, DVV 28\% ja DJV 17\% olid õppijakeeles asendatud vähem- või ebaoluliste struktuuridega DVV 28\%, DPV 27\%, DDV 22\%, DSV 10\%. See viitab omakorda keeleomaste struktuuride nihestunud või teisenenud kasutamisele, mis kajastub õppija tekstiloomes.

Sama tendents tuleb reljeefselt esile ka ülejäänud morfoloogiliste klasside verbist vasakul paiknevate keelestruktuuride võrdlemisel. Nii on ilukirjanduskeeles kõikide morfoloogiliste klasside adverbi sisaldavad klastrid invariandid, õppijakeeles aga perifeersed variandid (v.a VDV 24\%).

Konjunktsioonialgulise klassi J-V invariant emakeelekõneleja tekstiloomes on JDV, mis hõlmab 50\% selle klassi kolme klastri kasutusest (sest siin ei, et teinekord paneb, et vahest juhib, sest eile astus). JDV-struktuur asub osalause alguses, selle abil väljendatakse põhjuse-eesmärgi semantikat, tegu on alistusseosega. Võrdluseks: õppijakeele nelja klastri seas on JDV osakaal kõige väiksem: 13\% (ja alati tuleb, aga küll on, et siin on, ${ }^{*}$ et ei olla, et veel ei, kuid kindlasti ei) ja klassi J-D invariantne klaster on hoopis pronoomenit sisaldav JPV 44\% ( $j a$ ma olen, ja ta tuleb). 
Esineb nii alistus- kui ka rinnastusseos. Järelikult on emakeelekõneleja valik pealause ja kõrvallause sidumisel semantiliselt ning süntaktiliselt piiritletum kui õppijakeeles.

Substantiivialgulise klassi S-V invariant ilukirjanduskeeles on SDV 30\% (suudki lahti teha, maja valmis teha, vee peale valanud, süda natuke kripeldas, aeg möödas olema, vestlusega kaasa läinud). Selle klastri osakaal õppijakeeles on vaid $4 \%\left({ }^{\star} k o h t\right.$ siin sattus, lahing päriselt toimus, *arvutilaud kus seisab, päeval siin on, keeleoskus veel ei, nädal kohe ei) ja invariant on hoopis SVV jaatavas kõnes (ema peab minema, koor hakkab laulma, inimesed saavad elada), eitavas kõnes aga substantiiv-verbi eituspartikkel-verb (inimene ei saa, rahvas ei pea) - kokku 55\% kõigist S-V klassi kasutustest.

Pronoomenialgulise klassi $\mathrm{P}-\mathrm{V}$ invariant ilukirjanduskeeles on PDV 53\% (midagi ette võtta, ta äkitselt kadus, ma lihtsalt ei, ma õieti ei, ta enam ei), õppijakeeles vaid 6\% (ma veel ei, mina lihtsalt ei, ${ }^{*}$ ma ümber vaatan, ${ }^{*}$ mina halvasti sooritan, sulle kohe vastata, sa seal óppisid, ta lópuks tuleb) ning valdavalt kasutatakse hoopis eituspartiklit sisaldavaid PVV- ja PSV-struktuure (vastavalt 67\% ja 20\%), nt ma pean óppima, ma ei pea, ma ei ole, ta tahtis saada, ta ei saa; minu ema töötab, nende kirjad ei.

Klassi V-V invariant ja ainus klaster on ilukirjanduskeeles VDV (oli kinni toppinud, oli kokku tulnud), mis on õppijakeele kuue klastri seas 24\%-ga osakaalult teine (võib üle minna, peab õigesti riietuma, saab hästi elada), invariant on aga eituspartiklit sisaldav VVV 42\% (ei saa oppida).

Klassis A-V on ilukirjanduskeeles vaid üks mitteadverbiline struktuur adjektiiv-substantiiv-verb (ASV), samas kui õppijakeeles leidus neli klastrit, sh ADV 2\% (*uue lõpuks tuleb). Loomulikult ei tulnud see normile mittevastav struktuur ilukirjanduskeeles esile.

Emakeelekõneleja tekstiloomele pole omased ka klassid K-V ja G-V, kuid õppijakeeles need eristusid. Kaassõnaga algav klass $\mathrm{K}-\mathrm{V}$ sisaldab viit klastrit, sh KDV- ja KPV-struktuurid, mõlema osakaal on väikseim: $4 \%$ (<mille $>$ abil lausa elatakse). Genitiivartibuudiga algava klassi G-V invariant on mitteadverbiline struktuur GSV. 
Niisiis toob adverbi sisaldavate keelestruktuuride osakaalu võrdlus erinevates valimites välja järgmise seaduspära: mis emakeelekõneleja tekstikasutuses keskne, see õppija jaoks perifeerne. Järelikult ei tea õppija keeleüksuste kombineerimise olulisi printsiipe ega oska neid kasutada nagu emakeelekõneleja. Just sel põhjusel on õppija kirjutatud tekstid grammatiliselt ja semantiliselt vähesidusad, soovida jätab lausestuse sujuvus, morfosüntaktiline keerukus ja leksikaalne rikkus.

\subsection{Adverbialguliste struktuuride morfosüntaktiline} ja leksikaalne varieerumine ilukirjandus- ja õppijakeeles

Ilukirjanduskeeles on adverbiliste struktuuride leksikaalne ning morfosüntaktiline varieerumine piiratud, neil on kindlad tekstifunktsioonid (osa)lause alguses ja sees, nende struktuuride alusel genereeritakse uusi leksikaalseid üksusi (ühendverbid). Järgnevalt võrdlen klassi D-V struktuuride morfosüntaktilise ja leksikaalse varieerumise piire ilukirjandusja õppijakeeles.

Esiteks, ilukirjanduskeeles on adverbialguline DDV-struktuur klassi D-V invariant (50\%). Õppijakeeles on DDV osakaal poole väiksem: 22\%, selle morfosüntaktiline varieerumine piirdub jaatavas kõnes järgmiste juhtumitega: 1) adverbilist päritolu modaalsõna vaja + verbipartikkel + da-infinitiiv (vaja kokku saada, liita, panna, hoida); 2) rõhu-, modaalvõi hinnangusõna $+d a$-infinitiiv (vaja ka saada, väga palju lugeda (vaadata), nii ka teha, võimalikult hästi aidata) või mineviku liitaja vormi kuuluv nud-kesksõna (<on> väga vähe säilinud, <oli> eriti hästi säilinud, $<$ on> tõesti alati olnud) või preesensi ainsuse 3. pööre (väga kiiresti võib, siis rohkem meeldib, siis muidugi on). Leksikaalne varieerumine on üsna piiratud, eriti koos da-infinitiiviga, kus modaaladverbiga vaja kasutatakse valdavalt saama-verbi (vaja kokku saada, vaja ka saada); sageli on korratud adverbe väga, palju, hästi, võimalikult (väga palju lugeda, kaugelt hästi näha, võimalikult hästi aidata). Eristuvad nii loomulikud, ebaharilikud kui ka vigased trigrammid: 1) <saab> ilma ka hakkama, kui palju maksab (on), kuna seal oli, natuke üleval olla, nii ka teha, nii 
kiiresti areneb (lendab), siis tavaliselt maksab (meeldib), veelgi paremini valmistuda ning 2) ${ }^{*}$ siis rohkem meeldib, ${ }^{*}$ nii kas oli, ${ }^{*}$ ette kuidas saab, ${ }^{*}$ väga kuna on, ${ }^{*}$ seal kohal suri, ${ }^{*}$ palju jaoks tuleb, ${ }^{*}$ ühes kindlasti saab, ${ }^{\star}$ kõigest kiiresti <kõigist kiiremini> konspekteerida, ${ }^{\star}$ kõige muudkui tuleb, ${ }^{\star} k u s$ seal oli, ${ }^{*} k u h u$ edasi óppida <kuhu minna edasi óppima>, ${ }^{\star}$ hästi jaoks on.

Eitavas kõnes tuleb õppijakeeles esile stereotüüpne leksikaalgrammatiline muster küll üldiselt ei, harva on korratud mitte kunagi (alati, ainult) ei, siis ka ei, vist enam ei, nii nagu ei ja väga tihti ei. On ka ebaharilikke kooslusi nagu ${ }^{\star} \ddot{a r a}$ ilmselt ei, ${ }^{*}$ seal juurde ei, ${ }^{*}$ öösel kus ei, ${ }^{\star}$ veel $i k k a$ ei, ${ }^{*}$ veel palju ei jt. Nii jaatavas kui eitavas kõnes on üheks ebaharilike koosluste peamiseks põhjuseks nihestunud sõnajärg.

Ka ilukirjanduskeeles on DDV-struktuuri kasutatud nii jaatavas kui ka eitavas kõnes, kuid erinevalt õppijakeelest puuduvad siin leksikaalsed stereotüübid - iseloomulik on avar leksikaalne varieerumine. Sõna “avar” ei tähista adverbide ja proadverbide suvalist kooskasutust, vaid ainult niisuguseid kombinatsioone, mis sobivad kõnesolevale modaalset või ratsionaalset hinnangut andma, seda fookusesse tõstma, eelneva või järgneva infoga siduma. Verbivormi grammatiline varieerumine tuleb esile jaatavas kõnes. Võrreldes õppijakeelega on see avaram, grammatiliselt keerulisem ja erineva vormieelistusega: 1) tavaline on mineviku liitaega kuuluv nud-kesksõna: <on> väga tublisti kosunud, <olid> nii kangesti harjunud, 2) harvem predikatiivne ma-infinitiiv: $<$ hakkas $>$ aina rohkem meeldima, 3) imperfekti ja preesensi ainsuse 3. pööre: alles nüüd hakkas <ilmet võtma>, nii kangesti meeldib <matkata>, 4) objektina või liitpredikaadi koosseisus kasutatud $d a$-infinitiiv: nii sügavalt kummardada, täpselt samuti hiilata. Kuigi praegusel uurimisetapil jäi analüüsist välja seaduspärasuste leidmine kõneliigi, adverbi või proadverbi valiku ja verbi morfoloogia vahel, siis täiesti selge on DDV kui struktuuri olulisus erinevate lekseemide ja verbivormide ühendamisel tekstiliseks terviküksuseks, milles nii leksika kui (pro)adverbi funktsioonid (määruslik, modaalne, rõhuasetus, viiteseos) varieeruvad. Nende alusel saab struktuuri- ja vormianaloogiat rakendades ning leksikat varieerides 
produtseerida uusi keeleüksusi, sh mitmesõnalisi leksikaalseid kooslusi, mis paiknevad verbist vasakul (osa)lause alguses või sees.

Teiseks, järgmine oluline ilukirjanduskeele adverbialguline klaster on DVV (28\%), mis oppijakeeles on klassi D-V invariant (38\%). Emakeelekõneleja kasutab struktuuri DVV eitavas kõnes. Umbes neljandiku eitava kõne trigrammidest moodustavad ühendverbid, kus adverbist on saanud verbipartikkel: välja ei koorunud, maha ei rabanud, ära ei surnud, alt ei vedanud, taga ei nuta, järele ei anna, kinni ei võta, lahti ei saa jne. Ülejäänud juhtudel on adverb rõhusõna (ikkagi ei jäänud, ilmaski ei kõnni, küll ei ole, nii ei saa, sugugi ei rahuldanud, üldse ei meeldi), modaalne hinnangusõna (vist ei öelnud, tegelikult ei istu, lihtsalt ei saa, miskipärast ei soosinud) või erinevat liiki määrsõna (tähistab aega, kohta, hulka). Lause alguses on adverbil modaalsed (võib-olla, tegelikult, ilmselt - (mitte)tõeväärsuse hinnang) ja rõhutamise funktsioonid $(k a, j u)$. Lause sees esines adverbidest sagedamini enam tähenduses 'rohkem' (enam ei elagi, enam ei jaksa, enam ei juhtu; enam ei laabunud, enam ei maganud), harvem ilmnesid välja, üldse, veel, ikka(gi), ju, küll, maha jt. Struktuuri teine komponent on eituspartikkel ja kolmas verbi finiitvorm. Trigrammi ümbritsev morfosüntaktiline kontekst varieerub, (osa) lause ajaline plaan seostub verbi imperfekti ja preesensi vormidega (nt enam ei anna, välja ei ilmunud, üldse ei arvanud, veel ei liikunud), lause alguses vaid imperfektiga (Võib-olla ei olnudki, Sealpool ei olnud, Ka ei paistnud, Tegelikult ei olnud, Ilmselt ei tulnud, Teiseks ei mahtunud, Nüüd ei tulnud).

Õppijakeeles on DVV-struktuuri kasutatud ainult (osa)lause sees, trigrammid jagunevad enam-vähem ühtlaselt eitava ja jaatava kõne vahel. Eitavale kõnele on iseloomulikud kinnistunud sõna- ja vormivalikuga mitteidiomaatilised üksused, mis moodustavad nii loomulikke kui ka vigase keelekasutuse mustreid: üldse ei meeldi, üldiselt ei meeldi, $k a$ ei aita, kunagi ei loobu, kindlasti (veel) ei ole, isegi (lihtsalt) ei mõtle, enam ei jõua, seal ei anna, siin ei ole, praegu ei ole, ‘juba <enam> ei mäleta, ${ }^{*}$ täpselt <kohe > ei otsusta. Adverbi ülesanne on enamasti verbitegevuse negatiivse tulemuse rõhutamine ( $i k k a$ ei saa, ju ei mõtlegi, absoluutselt 
ei meeldi, eriti ei puudu), harvem modaalse hinnangu (tõepoolest ei saa, võibolla ei meeldi, ilmselt ei ole, paratamatult ei saa, tegelikult ei ole, tõesti ei oska, vist ei saa) ja määruslike tähenduste väljendamine (hiljem ei saa, praegu ei ole, homme ei ole, vahepeal ei saa - aeg; siin ei ole, kus ei ole, õues ei ole - koht; rohkem ei saa, palju ei tea, praktiliselt ei ole - hulk, määr). Õppijakeelele on tüüpilised eitava kõne verbikordused ei ole, ei saa, ei ütle, ei tea (590-st trigrammist 405-s), harva esinesid ei unusta, ei meeldi, ei mõtle(gi), ei oska, ainukordseid oli vaid üksteist - ei erine, ei jookse, ei kohtu jt. Valimis leidus kõigest üks ühendverbi näide - välja ei tule. Järelikult on DVV kasutamine õppija- ja ilukirjanduskeeles eitavas kõnes samalaadne vaid struktuuri poolest, kuid erineb lingvistiline sisu, st verbi grammatilised vormid, leksika valik, lekseemide kombineerimine. Ilukirjanduskeelele on omane adverbide avar leksikaalne varieerumine, ühendverbide kasutamine, imperfekti eelistamine, samas kui õppijakeeles tuleb esile eitava kõne verbikordustele tuginev stereotüüp preesensis: (pro)adverb + ei ole, ei saa, ei ütle, ei tea.

Ka jaatavas kõne puhul on õppijakeeles DVV-struktuuri üsna kesine leksikaalne varieerumine, seevastu verbi morfosüntaktiline varieerumine on avaram. Enamasti on tegu modaalse abiverbi ja infinitiivi (siis võib öelda, ${ }^{\star}$ edasi peab mäletama, kus saab kuulata, hiljem lubati esineda), harvem faasiverbi hakkama ja ma-infinitiivi ühendiga (hiljem hakkas tegelema, veel hakkas arenema, *sinna hakkas toibuma). Abiverbina on sagedamad võima, pidama, tahtma, olema indikatiivi preesensis. Järgnevad predikatiivne ma- ja da-infinitiiv (alati peab olema, hiljem võib olla), harvem objekti funktsioonis da-infinitiiv (koos armastavad laulda, tihti tahavad ühendada, hiljem lubati esineda). Kolmekümnest infinitiivi vormis kasutatud verbist on sagedamad olema, óppima ja leidma, ainukordseid leidus vaid neli (elama, tulema, ütlema, koguma). Jaatavas kõnes on DVV-struktuuri esimeseks komponendiks enamasti proadverbid kus, siis, siin - kus võivad viibida, kus sai kohata, siis võib kinnitada, siin võib olla. Adverbe on kasutatud tavaliselt ajamäärusena (täna (hiljem) võib olla, praegu saab leida, alati võib leida, mõnikord võib olla, nüüd võib küsida, varem olen óppinud), harvem hulga- (rohkem võib 
leida, rohkem meeldib õppida, vähe peab olema) ja viisimäärusena (kiiresti võib leida). Rõhusõnadena esinesid $k a$ ( $k a$ tahavad vaadata), ju (ju tahtsin óppida), veel (veel võib kirjutada), isegi (isegi võib teha), väga (väga tahab sõita).

Kolmandaks, ilukirjanduskeele klastri DJV osakaal on 17\%, õppijakeeles vaid 2\%. Ôppijakeeles oli DJV-struktuuri lausesisese rinnastuse näiteid (kokku ja hävitasid, omavahel ja laulsid, enne ning toimub, kohal ning areneb, rohkem ja võib, hästi ja ei). Verbi ajavormidest on preesens sagedam kui imperfekt, samas kui ilukirjanduskeeles on sagedam imperfekt ja preesens esineb harva. Õppija kasutab vaid ühte rinnastavat sidesõna - ja, emakeelekõneleja kahte - ja, ning. Ilukirjandustekstides ühendab rinnastusseos eelnevat partikkelverbi või kaassõnafraasi järgneva liht-, partikkelverbi või kaassõnafraasiga, nt <jättis> pooleli ja ronis $<$ puu otsa $>$, <mäe $>$ otsa ning tuli < kiiresti maja poole $>$ - seega on DJVstruktuuri morfosüntaks üsna keerukas. Õppija kasutab adverbi põhiliselt hinnangu-, rõhu- ja orientatsioonisõnana.

Neljandaks, ilukirjandus- ja õppijakeeles on kaks samalaadselt väheolulist klastrit: DSV (vastavalt 3\% ja 10\%) ning DAV (vastavalt 2\% ja 1\%). Emakeelekõneleja tekstiloomes sisaldab DSV-struktuur nii jaatavas kui ka eitavas kõnes objektikäändelist substantiivi, mis koos järgneva verbiga moodustab väljendverbe (<on, oli > ikka puhtust pidanud, <on, oli> ka märki tabanud, <polnud> veel aru saanud, <ei ole> üldse aru saanud, kuidagi sotti ei $<$ saanud $>$, siis aru ei $<$ saa $>$ ), harvem vabu sõnaühendeid (<nad olevat> juba kulu põletanud, <ta pole > kuhugi sedelit jätnud). Õppijakeeles on DSV-struktuuril hoopis teistsugune morfosüntaks ja leksikaalne varieerumine: substantiiv on reeglina nominatiivne subjekt (sagedamad: inimene, inimesed, lapsed, laul, palk, eestlased, elu jt); üle poole verbikasutustest moodustab olema-verbi preesensi vorm indikatiivis, harva esinesid modaalverb pidama (peab) ja liikumisverb tulema (tuleb, tulevad, tuli, tulid). DSV-struktuuri esikomponendiks on reeglina küsisõna (kus, kuna, millal, kas, kuidas), harvem proadverb siis. Tegu on kitsa leksikaalse ja morfosüntaktilise varieerumisega, esile tuleb muster kus (kuna, millal, kas, kuidas) + inimesed (inimene) + on, eitava 
kõne puhul stereotüüp palju (siis, isegi, $k a)+$ inimesed (inimesi, inimene) $+e i$. Ilukirjanduskeelele omased väljendverbid õppijakeeles sisuliselt puudusid, v.a ikka aru saada. Jaatava kõne DSV-struktuurides oli õppijal palju ebahariliku sõnajärjega trigramme jm vigast keelekasutust, nt ${ }^{\star}$ palju ópilased nimetasid <õpilased nimetasid palju>, ${ }^{\star}$ samuti meel on $<$ meel on samuti kurb>, ${ }^{\star}$ öösel pimedus on <öösel on pime>, ${ }^{\star}$ seal eeslaulja algab $<$ siis eeslaulja alustab $>,{ }^{\star}$ millal $<$ kui $>$ lumi sajab, ${ }^{\star}$ nii eestlasteks jätta $<$ jääda $>$, ${ }^{*}$ pisut $<$ vähe $>$ kursusele registreerunud.

DAV-struktuuri leidus verbist vasakul paiknevas kontekstis nii ilukirjandus- kui ka õppijakeeles väga harva: esimeses peamiselt (osa)lause alguses (kuivõrd kena (määrav) on, kui nõrk (hea) on, nii tuim on), teises (osa)lause sees (kõige tähtsam on, väga hea on, üsna raske on).

Viiendaks, ainult õppijakeelt iseloomustab DPV-struktuur (27\%), mis on DVV-struktuuri järel (38\%) osakaalu poolest teine. See on tingitud õppijakeele ebaloomulikust sõnajärjest (vt eespool, samuti Kaivapalu 2010), vene emakeelega õppija keelemeelelisest mina-kesksusest, oskamatusest kasutada (pro)adverbe sisaldavaid struktuure nagu emakeelekõneleja.

Jaatavas kõnes on DPV-struktuur kolm korda sagedam kui eitavas kõnes. Trigrammides kasutatakse valdavalt ainsuse 1. isiku lühivormi subjekti funktsioonis (siis ma helistan, siis ma lähen, sellepärast ma arvan, praegu ma õpin, kus ma tahan, kuhu ma lähen), harva ka demonstratiivpronoomenit see (siis see on, nii see oli, vanasti see oli). Valdajamäärusena esinesid adessiivsed personaalpronoomenid mul, sul ja tal (siis mul on, praegu mul on, miks sul on, siis sul on, siis tal on). Verbivormidest on eelistatud indikatiivi preesensi ainsuse 1. pööret (pean, tahan, lähen, arvan, saan, olen), harvem on kasutatud imperfekti (sain, unistasin, pidin, óppisin), näiteid leidus ka konditsionaali preesensiga (tahaksin).

(Pro)adverbide valik ja leksikaalne varieerumine on seotud isikuga. Kõige avaram on esikomponendi leksikaalne varieerumine ainsuse 1. isiku lühivormiga (siis, kus, praegu, kuhu, miks, veel, sellepärast, nüüd + ma); kõige kasinam ainsuse 2. ja 3. isiku ning mitmuse 1. ja 3. isiku lühivormidega: kus, kuhu, kuidas + sa; kas, kus + ta; siis, kus + me ja kus, 
kuidas + nad. Sama tendents on jälgitav ka adessiivse valdajamääruse puhul: siis, palju, sellepärast, veel, seal + mul; miks, siis + sul; siis + tal.

Verbide leksikaalsel varieerumisel kordub sama skeem. Tegu on õppijakeele leksikaalgrammatilise stereotüübiga. Sama struktuuri raames on komponentide kooskasutusel selged leksikaalgrammatilised piirangud ja piirid. Stereotüübi kujunemisel on oma osa õppija emakeele mõjul tekkinud vigadel nagu adverbi sisaldavate struktuuride ebaharilik sõnajärg, personaalpronoomeni pika ja lühivormi valik ( ${ }^{*}$ palju mina sain $<$ ma sain palju mida $>$ ), adverbilise komponendi, personaalpronoomeni pika ja lühivormi ning verbi ajavormi valik ( ${ }^{*}$ pärast mina mõtlen $<$ pärast, siis ma mõtlesin, et ... >), mittevajalik mina-rõhutamine $\left({ }^{\star} k\right.$ us mina töötasin <kus ma töötasin $>$ ), adverbide semantika, vaatluspunkti erinemine (nt enne vs. varem $-{ }^{\star}$ enne mina arvasin $<$ varem ma arvasin, et ... >), põhjusliku seose väljendamine lauses ( ${ }^{*}$ sellepärast $<$ vn поэтому> ma tahaksin <seepärast, seetõttu ma tahaksin>), tingimuse ja ajatähenduse segamine, nt sidend kui ... siis (vn если ... mo ja teisalt $\kappa о г д а ~ . . . ~ т о г д а, ~ m i l l e ~ t u l e m u s e k s ~ o n ~{ }^{\star} k u i$ mina väsisin, siis ma magan $<$ kui olen väsinud/kui ära väsin, (siis) lähen magama $>$ ) jm.

Eitavas kõnes on kasutatud kolme liiki DPV-struktuure, mis sisaldavad tavaliselt ainsuse 1. ja 2. isiku personaalpronoomenit subjekti funktsioonis (praegu, siis, miks, veel ma ei), harvem indefiniitset keegi-miski subjekti (mitte keegi/miski ei), midagi objekti funktsioonis (mitte midagi ei) ja adessiivset valdajamäärust mul (miks, sellepärast mul ei). Adverbilise esikomponendi kasutamisel ilmnevad samad tendentsid, mida kirjeldasin eespool seoses jaatava kõnega: praegu, siis, miks, veel, kahjuks, muidugi, sellepärast, täpselt + ma (mina); siis, kust + ta; sellepärast, miks + mul. Indefiniitseid pronoomeneid on kasutatud kahekordse eitusega: mitte + indefiniitne pronoomen + verbi eituspartikkel ei. Eitava kõne stereotüüpides leidus vähem ebaharilikke leksikaalgrammatilisi kooslusi, kuid sõnajärg ja adverbilise esikomponendi semantiline sobivus on nii mõnelgi juhul kaheldav: ${ }^{\star}$ täpselt $m a$ ei $<$ ma ei tea täpselt $>,{ }^{\star}$ veel juba ma ei <ma ei ole veel $>$, *millal ma ei, ${ }^{*}$ järel ma ei, ${ }^{*}$ peale ma ei, ${ }^{*}$ sellepärast mul ei. 
Niisiis on õppijakeele DPV-struktuur kujukas näide, mis toimub, kui õppijal pole teadmisi ja oskust 1) kombineerida (pro)adverbe muude sõnaliikide ja vormidega, arvestada komponentide semantilise sobivuse ja võimaliku-ebasobiva-mittevõimaliku järjestusega ning 2) kasutada adverbi sisaldavaid struktuure samades tekstilistes funktsioonides kui emakeelekõneleja. Senised teadmised on pigem tunnetuslikku laadi ja kogemuspõhised kui uurimistulemustele tuginevad. See kajastub eesti keele kui teise keele ainekavas ja enamikus kasutusel olevates õpikutes, kus seos õppeteksti, temaatilise sõnavara ja grammatikaõpetuse vahel tegelikult puudub, grammatikareeglite valik on juhuslik, seletused eklektilised, mis ei võimalda kujundada süsteemseid grammatikateadmisi, rääkimata kasutusgrammatikast (vt Ševtšenko 2014).

\section{Kaks järeldust}

Klasteranalüüs võimaldab esile tuua tekstikasutust iseloomustavaid tendentse, leida regulaarselt kasutatavad mitmesõnalised kooslused, avada nende funktsionaalne potentsiaal, seletada nende olulisust tekstiloomes, kirjeldada leksikaalse ja morfosüntaktilise varieerumise piire. Seega on meetod sobiv, aitab üle saada lingvistiliste kirjelduste kitsaskohtadest või juurdunud arusaamadest, kuna ei tugine keelesüsteemile, vaid tekstilistele terviküksustele, mida niisugustena tajutakse, talletatakse mälus ja produtseeritakse. Oluliseks osutuvad keelekasutaja eelistused, kuidas struktuure, lekseeme ja vorme kombineeritakse ning varieeritakse. Selles võib ilmsiks tulla palju huvitavat. Näiteks eesti ilukirjanduskeele klasteranalüüsi tulemuste põhjal ei saa väita, nagu oleks substantiivid, adjektiivid ja verbid kolm kõige olulisemat sõnaliiki, sest suurim osakaal valimis on adverbi sisaldavatel trigrammidel ja adverbil kui sõnaliigil. Nii on adverbialguline klass $\mathrm{D}-\mathrm{V}$ morfoloogiline invariant, adverbilised on ka ülejäänud klasside invariantsed klastrid. Adverbil on eesti ilukirjanduskeele tekstikasutuses avar funktsionaalne potentsiaal leida rakendust eri liiki määrustest kuni verbi- ja sidususpartikliteni. Tekstilistest funktsioonidest on olulisemad viiteseosed, modaalne hinnang 
ja rõhutamine, millega tagatakse tekstide sidusus ja esituslaadi sujuvus. Teisalt kuuluvad adverbi sisaldavad struktuurid eesti keele varamusse, mille alusel saab vabalt moodustada uusi leksikaalseid üksuseid, nt verbist vasakul peamiselt ühendverbe, harvem ka väljendverbe. Adverbi sisaldavate struktuuride komponentide järjestus võib lauses varieeruda olenevalt sellest, mida kõneleja soovib fookusesse tõsta.

Adverbide leksikaalne varieerumine on üldiselt vabam kui verbidel ja substantiividel. Nende morfosüntaks on piiratud, samas grammatiliselt üsna keeruline, nt mineviku ajavormid, liitpredikaadid. Olenevalt trigrammi struktuurist, funktsioonist ja adverbilise komponendi asendist selles võib märgata adverbide ja proadverbide kasutuserinevusi.

Eesti õppijakeeles on adverbi sisaldavaid struktuure välditud, nende esinemus on perifeerne ja nihestunud. Struktuuri küll kasutatakse, kuid selle lingvistiline sisu erineb. Põhjus on lihtne: ei saa õpetada, ammugi õppida seda, mille kohta puudub teadmine. Meil on sõnastikud, grammatikad ja süsteemsed kirjeldused, kuid pole eesti keele kasutusgrammatikat ja pedagoogilist grammatikat. Me oleme pikka aega õpetanud eesti keelt kui riigikeelt, sh teise keelena samadel alustel nagu emakeelsele inimesele. Oleme õpetanud tekste produtseerima katse-eksimise meetodil, mitte teadmistepõhiselt. Arvestades eesti keele kui riigikeele õppe olukorda, sh õpikud, õppematerjalid, tasemeoskuste kirjeldused, tasemeeksamite sisu ning tööd, mida riigikeele paremaks omandamiseks on tehtud ja tehakse, olen sunnitud tõdema, et see on valdavalt kogemus- ja juhtumipõhine ning üsna vähe teadmistele tuginev. $\mathrm{Me}$ lihtsalt pole uurinud ega tea, millele emakeelekõneleja tekstiloome tugineb, missuguseid keelestruktuure, vorme ja leksikat omavahel tüüpiliselt/ebatüüpiliselt kombineeritakse, mida eelistatakse ja miks, kuidas see on seotud erinevate suhtlusvajaduste, keeleoskustasemete kujunemisega jm. Artiklis kirjeldatud analüüs näitab, et tekstiloomes kõige olulisemate ja sagedamini kasutatud adverbi sisaldavate keelestruktuuride funktsionaalset potentsiaali kasutab õppija vaid osaliselt, asendades emakeelekõneleja jaoks olulised struktuurid vähem- või ebaolulistega. Järelikult vajab õppija teadmisi keeleüksuste kombineerimise põhimõtete kohta 
ning oskust neid rakendada lugemisel, tekstide mõistmisel, suulisel ja kirjalikul tekstiloomel.

Adverbi sisaldavate struktuuride morfosüntaktilise ja leksikaalse varieerumise piirid ning sõnajärg lauses vajavad veel uurimist. Pole selge, milleks neid struktuure eri liiki tekstide produtseerimisel tüüpiliselt vaja läheb. Samas näitab eespool kirjeldatud adverbistruktuuride kasutus, et neil on kindlat liiki tekstifunktsioone, mida tuleks arvestada eesti keele õpetamisel, k.a eesti keele õpetamisel emakeelena, eriti seoses muutustega määruslike laiendite sõnajärjes. Kogemuspõhisele lähenemisele vastandub uurimise tulemusel saadud teadmine keele elementide kombineerimisest ning leksikaalsetest ja morfosüntaktilistest piirangutest, mis seejuures ilmnevad. Lingvistiline klasteranalüüs ja n-grammide kasutamine annavad võimaluse niisugust teavet saada.

\section{Kirjandus}

Anthony, Laurence 2013. A critical look at software tools in corpus linguistics. Linguistic Research 30 (2), 141-161.

Chodorow, Martin, Claudia Leacock 2000. An unsupervised method for detecting grammatical errors. - NAACL 2000 Proceedings of the 1st North American chapter of the Assotiation for Computational Linguistics conference. Stroudsburg, USA: Assotiation for Computational Linguistics, $140-147$.

Conklin, Kathy, Norbert Schmitt 2008. Formulaic sequences: Are they processed more quickly than nonformulaic language by native and nonnative speakers? - Applied Linguistics 29 (1), 72-89. http://dx.doi.org/10.1093/applin/ amm022

Eslon, Pille 2013. Kahe keelekasutusvariandi võrdlus: morfoloogilised klassid ja klastrid. - Lähivõrdlusi. Lähivertailuja 23, 13-38. http://dx.doi. org/10.5128/LV23.01

Eslon, Pille 2014. Morfosüntaktilise ja leksikaalse varieerumise piiridest: ilukirjandus- ja õppijakeele kasutusmustrite võrdlus. - Eesti Rakenduslingvistika Ühingu aastaraamat 10, 55-71. http://dx.doi.org/10.5128/ERYa10.04

Evert, Stefan 2005. The Statistics of Word Cooccurrences, Word Pairs and Collocations. PhD dissertation. Institut für maschinelle Sprachverarbeitung Universität Stuttgart. 
Ibbotson, Paul 2013. The scope of usage-based theory. - Frontiers in Psychology 4 (article 255), 1-15. http://dx.doi.org/10.3389/fpsyg.2013.00255

Kaalep, Heiki-Jaan, Kadri Muischnek 2009. Eesti keele püsiühendid arvutilingvistikas: miks ja kuidas. - Eesti Rakenduslingvistika Ühingu aastaraamat 5, 157-172. http://dx.doi.org/10.5128/ERYa5.10

Kaivapalu, Annekatrin 2010. Mõnede eesti sõnajärjemallide psühholingvistilisest reaalsusest. - Eesti Rakenduslingvistika Ühingu aastaraamat 6, 103-120. http://dx.doi.org/10.5128/ERYa6.07

Krikmann, Arvo 2004. "Sai hea obaduse vastu obadust": löömist ja peksmist märkivad väljendid eesti keeles. Reetor 3. Tartu: Eesti Kirjandusmuuseumi folkloristika osakond, eesti kultuuriloo ja folkloristika keskus.

Küngas, Annika 2014. Põhimõtteliselt või praktiliselt Paides - kahe sarnase funktsiooniga sõna käekäigust. - Eesti Rakenduslingvistika Ühingu aastaraamat 10, 209-226. http://dx.doi.org/10.5128/ERYa10.13

Masini, Francesca 2005. Multi-word expressions between syntax and the lexicon: The case of Italian verb-particle constructions. - SKY Journal of Linguistics 18, 145-173. http://www.ling.helsinki.fi/sky/julkaisut/SKY2005/ Masini.pdf (30.5.2014).

Metslang, Helle, Karl Pajusalu, Külli Habicht 2014. Koordinatiivsed partiklid lause perifeerias. - Emakeele Seltsi aastaraamat 59 (2013), 139-161. http:// dx.doi.org/10.3176/esa59.07

Meurers, Detmar W. 2005. On the use of electronic corpora for theoretical linguistics. Case studies from the syntax of German. - Lingua 115 (11), 16191639. http://dx.doi.org/10.1016/j.lingua.2004.07.007

Muischnek, Kadri, Heete Sahkai 2010. Liitpredikaadid leksikoni-grammatika kontiinumil: konstruktsioonide produktiivsusest verbiga minema moodustatud liitpredikaatide näitel. - ESUKA - JEFUL 1 (2), 295-316.

Ots, Sander 2012. Statistikapõhise tarkvara loomine morfoloogiliste kollokatsioonide eraldamiseks eesti keele tekstidest. Bakalaureustöö. Käsikiri TLÜ informaatikainstituudis.

Sinclair, John 1991. Corpus, Concordance, Collocation. Oxford: Oxford University Press.

Ševtšenko, Marina 2014. Eesti keele kui teise keele 8. klassi õpiku temaatiline sõnavara ja grammatika. Magistritöö. Käsikiri Tallinna Ülikooli eesti keele ja kultuuri instituudis.

Trainis, Jekaterina, Kais Allkivi 2014. Ilukirjanduskeelest uue pilguga. - Eesti Rakenduslingvistika Ühingu aastaraamat 10, 283-306. http://dx.doi. org/10.5128/ERYa10.18 
Valdmets, Annika 2010. Mõne modaalpartikli kujunemine ja kasutamine eesti kirjakeeles alates 1890. aastatest. Magistritöö. Käsikiri Tartu Ülikooli eesti ja üldkeeleteaduse instituudis.

Valdmets, Annika, Külli Habicht 2013. Episteemilistest modaalpartiklitest eesti kirjakeeles. - ESUKA - JEFUL 4 (1), 205-222. http://dx.doi.org/10.12697/ jeful.2013.4.1.12 


\title{
On the textual functions of adverbial structures in literary Estonian and in Estonian learner language
}

\author{
PILLE ESLON \\ Tallinn University
}

The article describes the most essential trigrams of literary Estonian, namely, those containing adverbs. If positioned left of the verb, such trigrams have a number of textual functions such as reference, modal assessment, and emphasis, which provide for the coherence and fluency of the text. At the same time, adverbial structures are a mobile treasury of the Estonian language, enabling production of new lexical combinations, which in the left context are mainly particle verbs (hästi välja tuleb 'succeeds', ootamatult peale sattuda 'unexpectedly stumble upon', siit ära minna 'leave the place'), and sometimes phrasal verbs (ikka puhtust pidanud '[has] always kept clean', ka märki tabanud '[has] even hit the mark'). In Estonian learner language, adverbial structures are a marginal phenomenon characterized by deviant usage, i.e. the structure is the same, but differences are manifested in its lexical and/or morphosyntactic variation. Learners tend to use lexico-grammatical cliches (e.g. kus inimesed on 'where people are', siis inimesed $e i$ 'then people do not'), their vocabulary is restricted, while the word order and semantic relations are often indicative of unusual or faulty use of language, which is supported by the influence of the learners' mother tongue. This is inevitable as long as the learners produce texts without knowing the rules of using adverbial structures in text production.

Keywords: Estonian literary language; Estonian learner language; multi-word co-occurrences; textual functions of adverbial structures; cluster analysis; n-grams

\section{Pille Eslon}

Tallinna Ülikooli informaatika instituut

Narva mnt 25

10120 Tallinn, Estonia

pille.eslon@tlu.ee 